\title{
THE RECARDIAN THEORY OF COMPARATIVE ADVANTAGE BETWEEN SOUTH AFRICA AND THE USA IN THE MANUFACTURING SECTOR
}

\author{
O A Akanbi and A C Jordaan*
}

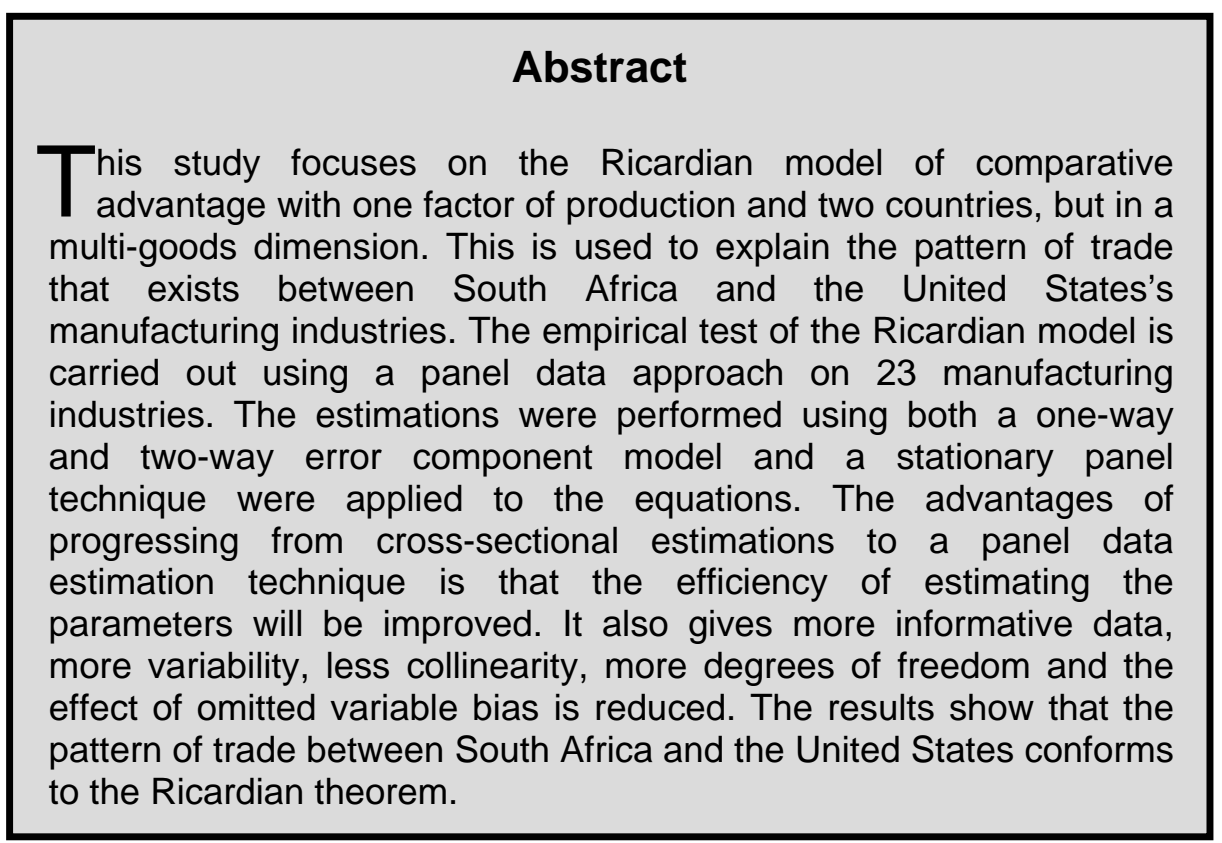

\section{Introduction}

It is evident in this new millennium that the world economies are getting more integrated especially in the area of international trade. This is a key feature of a process that is termed as globalisation. Globalisation is a process of moving toward free trade among the world economies. In this regard, openness or the degree of integration of any economy into the international community depends on the extent of that economy's involvement in international trade, which is manifested in its balance of payment. Romer (1992) and Barro and Bala-i-Martin (1995) argue that an increase in trade implies greater openness, which then facilitates an economy's use of more efficient techniques of production. Therefore, an increase in exports weakens the foreign exchange constraint and gives room for greater imports of key inputs in the production process (Miller \& Upadhyay, 2000).

\footnotetext{
* Department of Economics, University of Pretoria, Pretoria 0002, Republic of South Africa. Email: segakanbi@yahoo.co.uk or andre.jordaan@up.ac.za
} 
The major features of South Africa's exports have been changing since the election of a new democratic government in 1994, which has led to many policy reforms in the country. These reforms are expected to transform the major structures of the economy, which should also improve the country's comparative advantage especially in the manufacturing sector. In this era of globalization it is imperative to investigate the pattern of trade of a country with the rest of the world.

Over the last ten years, the United States has been the biggest trading partner (total trade) of South Africa and the total trade between these two countries has also been increasing over the years (Anon, Available url accessed). Generally, access to South African markets in recent times has been on the increase, and the U.S exports to South Africa far exceed its exports to any other country in Sub-Saharan Africa. Despite the U.S gains, benefits have also been accruing for South Africa from the U.S's Generalised System of Preferences (GSP), which grants duty-free status to about 4650 goods (Anon; Available url accessed). The bilateral co-operation forum between the two countries has been boosting the trade between the two countries and the African Growth and Opportunity Act (AGOA), which allows duty-free exports to the U.S, has also contributed to the increases in the pattern of trade between these countries.

The South African economy is characterised by a developed, well-established and diversified manufacturing sector that has the potential to compete effectively in the global market. The manufacturing sector invariably, serves as an engine to the growth and development of any economy if it is explored appropriately (Anon, Available url accessed).

The main objective of this paper is to test whether or not the Ricardian theory of comparative advantage in the manufacturing sector is applicable to South Africa as stipulated. The method followed is to see whether the Ricardian theory is strictly determined by productivity differences or differences in unit labour cost.

The rest of the paper is organized as follows; Section Two presents the foundation of the Ricardian doctrine (theory and critique). In Section Three previous empirical tests carried out on the Ricardian model are presented and Section Four presents the theoretical framework and methodology used in the paper and also describes the data that are used. In Section Five an analysis of the results of the various estimations and diagnostic tests conducted in the paper are presented and lastly, Section Six concludes the paper.

\section{The foundation of the Ricardian doctrine: Theory}

The free trade theory propounded by Adam Smith ((1776) 1965) in his work An inquiry into the nature and causes of the Wealth of Nations has contributed significantly to the international trade literature. This work has specified that the freedom from any restrictions should lead to free trade and competition both at home and abroad. Based on Adam's Smith's great work in all spheres of economics he has been bestowed with the title of the 'Father of Economics' but his analysis of 
international trade has not been widely put into practice due to his failure to develop the comparative advantage principle (West,1990).

Smith's free trade theory was based on the critical doctrines of the Mercantilists, which were popular in the $17^{\text {th }}$ century. He was one of the most important philosophers who were responsible for the downfall of the Mercantilist school of thought in the area of international trade. His theory refutes the notion of selfsufficiency (autarky), which was common then among many countries that wanted to be independent from other countries. He argues that, no economy can produce all its needs and that all countries will benefit if each can specialise in the production of certain goods. He emphasized this benefit of specialisation in his famous book An inquiry into the nature and causes of the Wealth of Nations.

Following the theory of absolute advantage, propounded by Adam Smith, is the theory of comparative advantage. James Mill gave the credit for the discovery of comparative advantage to Ricardo. This confirmation by James Mill is what is termed today as the 'Ricardian Law of Comparative Advantage'. Ricardo's discovery of the law of comparative advantage must rank as one of the most remarkable discoveries in the history of economic thought (Ruffin, 2002: 735).

One of the most important points made by Ricardo (1817), is that it will be beneficial for each country to specialise in the production of the goods in which it has the highest absolute advantage. In so doing, each country will eventually enjoy the benefits of comparative advantage and this will facilitate trade between them. Each country will be able to export the good to where its comparative advantage is highest.

According to Ricardo, each country will benefit from trade if the opportunity cost of production differs between the two countries. But no international trade can occur if the opportunity cost of production between the two countries is the same. The idea of differences in opportunity cost of production was refuted by Leontief (1933: 499), when he tried to analyse international trade based on equal opportunity cost, but differences in the terms of trade. Bhagwati (1967: 76), also refuted the Ricardian theory when he tested the Ricardian model based on differences in the terms of trade and found that not only can trade take place in this situation but the pattern of trade will even be reversible as well.

The major assumptions underlining the Ricardian theory are that, there are two goods, two countries, only one factor of production (labour), constant cost, and can only be practiced in the world of perfect competition. He also assumes that technology differs across countries and that there is perfect mobility of labour within each country but perfectly immobile internationally. Bhagwati (1964: 7) pointed out that there is nothing in the original framework of the Ricardian model that says that the single factor assumption should be labour. He said that it could be any other factor of production, but labour has mostly been taken as the single factor. This may be because labour is still seen as one of the least mobile factors in any production process. 
However, the main strength of this theory, which makes it more relevant in the analysis of trade pattern, is the assumption of differences in technology across countries. Ricardo laid major emphasis on this realistic assumption that the technological superiority of a country over other countries can be a source of comparative advantage. This is what is still giving the Ricardian theory an edge over other theories in explaining the pattern of trade (Feenstra, 2004: 1) for these facts.

\section{Empirical tests of the Ricardian model of comparative advantage}

Despite all the changes in the assumptions underlining the classical and neoclassical trade theories, the fact still remains that the basic foundation of any international trade theory mostly begins with the classical Ricardian theory of comparative advantage. Its serious contribution in the field of international trade was the major emphasis it placed on the assumption that technology differs across countries, which is evident in the modern pattern of trade. The theory is built on the assumption that relative productivity differentials determine trade patterns. But the Ricardian doctrine has been somehow abandoned in the literature since it was propounded in the $18^{\text {th }}$ century. His idea started gaining recognition again in the early 1950s when some empirical tests were carried out.

Previous empirical tests conducted on the Ricardian model of comparative advantage have contributed significantly to the literature. MacDougall (1951), who pioneered the empirical test of the Ricardian theory, in his study found that in 1937 there was a strong inverse relationship between relative US, and UK wage costs per unit of output and relative exports. A positive relationship existed between relative output per worker (relative labour productivity) and relative exports. These results really follow the Ricardian theory of comparative cost advantage. MacDougall's (1951) study was based purely on cross-sectional estimations for 1937.

The verification of certain aspects of the comparative advantage that existed between America and Britain was carried out by Stern (1962) 10 years after MacDougall's empirical test. He used cross-sectional estimations to carry out similar tests and found that comparative costs explain significantly relative exports performance of Britain and America in 1950 and 1959. This corresponds to the conclusion reached by MacDougall (1951). Interestingly, Stern (1962) points out an important fact in the literature that the comparative advantage of any country is not static as assumed in the Ricardian doctrine. He found that the lower productivity country (Britain) gains in the higher productivity industries and the higher productivity country (America) gains in the lower productivity industries. This has made a great contribution to what Graham (1932) highlighted. Meaning that no country, in any way, can have a permanent technological superiority in its export industries. Therefore, comparative advantage as mentioned by Graham is a moving line and cannot be taken as given.

Solocha (1991) examined the relationship that exists between the components of unit labour costs, productivity, and wages to the structure of United States trade 
flows in manufacturing industries. He found that differences in labour productivity in the manufacturing industries play an important role in determining trade patterns in the United States. The parameter estimates found from his study can be said to be more reliable since a panel data model was used in his analysis. This corresponds to the earlier work of MacDougall (1951), Stern (1962), and Balassa (1963) who base their studies only on cross-sections also to that of Stryker (1968: 165) who uses a time series approach to address the problem of trade restriction biases.

Time-series and cross-sectional tests of the Ricardian model based on the behaviour of sectoral trade balances were performed by Golub (1994: 307). He used the calculated unit labour costs and trade balance for several sectors in seven major industrial countries. The main finding was that, the unit labour costs, especially for U.S and Japan, significantly explain the changes that occurred in sectoral trade balances. This finding conforms to the Ricardian theory. But he suggested that further research should attempt to remedy some of the shortcomings of the data used in the paper by trying to disaggregate the data further and extend the analysis to the service sector since it is the fastest growing sector in the area of international trade.

Golub and Hsieh (2000: 231) assessed the Ricardian model for United States trade. They performed a cross-sectional Seemingly Unrelated Regression (SUR) of sectoral trade flows on relative labour productivity and unit labour cost for a number of countries. Their results provide strong evidence that the Ricardian theory, despite its simplicity continues to perform very well empirically.

Further investigations on the Ricardian model to test the relationship between export shares and relative unit labour costs were also carried out in Carlin, Glyn and Van Renen. (2001: 138). They uses a panel of 12 manufacturing industries across 14 OECD countries. Their findings correspond strongly to the theoretical foundation of the Ricardian model. They also discovered that there are other variables like technology and institutional factors that can really influence the performance of exports. They found a good support for the role in which these two factors are playing in determining the pattern of trade. Although, subsequent empirical work on these additional variables has not been done they have expected to see a confirmation of their work in future research so that policy implication can follow.

However, based on the above empirical analysis, very few recent empirical tests of the Ricardian theory of comparative advantage have been carried out in South Africa. There have been papers written or presented based on export performance and trade competitiveness of South Africa. But they are not specifically based on testing whether the Ricardian theory holds in South Africa or not. Regardless of these limitations there are still a few recent empirical tests conducted, using South Africa as a study, which are verified below.

In an extension of Golub and Hsieh (2000: 231), Edward and Golub (2002: 14) performed an empirical test on South Africa's export performance based on the 
Ricardian model. Their focus was on the changes that occurred to cost competitiveness of the South Africa labour at a sectoral level. They compared relative unit labour costs across a wide range of countries and found that South Africa is cost competitive with the developed countries, but not with the developing countries. In their estimations, a dynamic panel data analysis was used in order to determine the long-run relationship between unit labour costs and export performance.

Kohler and Bruce-Brand (2003: 12) in their study found that labour costs per unit of output were very significant in determining trade competitiveness in the manufacturing industries in South Africa. Similar results were found in Balassa (1963), who uses relative productivity and relative factor cost in determining the export share of the United States and United Kingdom. Although, their studies give a robust evidence of the Ricardian theory of comparative advantage, their findings on relative wages was not all that convincing to support the Ricardian doctrine of comparative advantage.

\section{Theoretical framework and methodology}

The framework used in this paper follows the work of Golub and Hsieh (2000) who presented a framework based on international comparisons of unit labour costs for analysing international competitiveness. This framework was also adopted by Edwards and Golub (2002) who realized its usefulness when applied to the South African context. It is formally presented as follows:

Assuming there are two countries $\mathrm{X}$ and $\mathrm{Y}$ represented as domestic and foreign country respectively. Let $a_{i}$ represent unit labour requirements (i.e inverse of productivity), for industry $i$. Such that:

$\mathrm{a}_{\mathrm{i}}=\mathrm{L}_{\mathrm{i}} / \mathrm{Q}_{\mathrm{i}}$

where

$\mathrm{Q}$ is the value added for $\mathrm{i}$, and $\mathrm{L}$ is the labour employment for $\mathrm{i}$. The unit labour cost is the cost of labour per unit of output (i.e. the ratio of wages to productivity), which is given as:

$$
\begin{aligned}
& \mathrm{X}=\mathrm{a}_{\mathrm{i}} \mathrm{w}_{\mathrm{i}} \\
& \mathrm{Y}=\mathrm{a}_{\mathrm{i}}^{*} \mathrm{w}_{\mathrm{i}}^{*}
\end{aligned}
$$

The unit labour requirement $\left(a_{i}\right)$ is also the inverse of marginal productivity $\left(1 / a_{i}\right)$, and can be assumed to be constant with respect to variations in $\mathrm{L}_{\mathrm{i}}$. 
This framework follows strictly, the Ricardian assumption of two countries. The assumption of two goods will be relaxed since the number of industries to be investigated is more than two. This means that it is no longer possible to maintain the strong Ricardian theorem which states that the pattern of trade is determined exclusively by differences in factor productivity (Bhagwati, 1964: 5).

Therefore, the competitiveness of industry $\mathrm{i}$ in country $\mathrm{X}$ compared to country $\mathrm{Y}$ will also depends on the wages $\left(\mathrm{w}_{\mathrm{i}}\right)$ and the bilateral exchange rates (e) of the two countries. These two variables determine the relative unit labour cost which serves as the preferred factor that drives the pattern of trade.

One of the assumptions underlying the Ricardian theory as mentioned above, is that, labour is the only factor of production. Therefore, in country X, the average cost of production will be equal to its unit labour costs (ULC) as expressed in equation 2(a) in domestic currency (Rand), and country Y's unit labour costs (ULC) as expressed in equation 2(b). In order to have a common currency for ULC in both countries equation 2(b) is multiplied by the bilateral exchange rates so that it can be expressed in domestic currency (Rand) and is given below as:

$\mathrm{Y}=\mathrm{e} \cdot \mathrm{w}_{\mathrm{i}}^{*} \cdot \mathrm{a}_{\mathrm{i}}^{*}$

The use of bilateral exchange rates to convert the ULC of both countries into a common currency is adopted since the framework involves only two countries.

The competitiveness of each sector in both countries now depends on the relative unit labour costs $\left(\right.$ RULC $\left._{\mathrm{i}}\right)$. Dividing 2(a) by 2(c) yields:

$$
\operatorname{RULC}_{i}=\frac{a_{i} w_{i}}{a_{i}^{*} w_{i}^{*} e}
$$

The above can also be re-expressed as:

$$
\operatorname{RULC}_{\mathrm{i}}=\frac{\mathrm{a}_{\mathrm{i}}}{\mathrm{a}_{\mathrm{i}}^{*}} \cdot \frac{\mathrm{w}_{\mathrm{i}}}{\mathrm{w}_{\mathrm{i}}^{*} \mathrm{e}}
$$

Equation (4) decomposes the relative unit labour costs into relative productivity and relative wages all expressed in common currency (Rand). This means that country X's competitiveness compared to country Y's can improve if labour productivity in country X rises relative to that of country Y's or its relative wages falls. If this improvement is experienced, it is expected to see an increase in the exports of $X$ to $\mathrm{Y}$ and a reduction in its imports from $\mathrm{Y}$. However, country $\mathrm{X}$ will have an absolute advantage in sector $i$ where the unit labour costs are below that of country Y. That is to say that, a decline in RULC over the years will increase exports and decrease imports. Also those industries with a lower RULC will have larger export shares. 
However, previous empirical studies especially the pioneering works of MacDougall (1951: 698), Stern (1962: 277), and Balassa (1963: 232) have used cross-sectional data for a given year in analyzing the Ricardian comparative advantage theory. Few empirical literatures (especially the recent studies) have tested the Ricardian theorem using the panel data approach.

Investigating the theoretical relationship that exists between productivity and export quantities, it is expected that there should be a positive correlation between labour productivity and export quantities. The reason behind this is that, as the output per worker of a particular industry increase, the products also become cheaper, which allows greater exports in that industry. So, an industry that has a relative productivity advantage will tend to have larger export shares. This hypothesis that there is a linear relationship between relative productivity and relative export has been found in almost all the empirical research including the works of MacDougall (1951), Stern (1962) and Balassa (1963).

There seems to be an ambiguous relationship that exists between wages and export quantities when taking wages into consideration as a determinant of export. Balassa (1963: 236) confirmed this from the results of his tests and concluded that there is no definite relationship between relative wages and relative export. This means that lower relative wages (i.e as it is being explained theoretically) could lead to substantially higher export shares. But there is some inconclusive evidence as pointed out by Balassa (1963) that higher relative wages might be associated with higher export shares. If that is the case, then higher export shares may also make it possible to pay higher wages. The implication is that there is no uni-directional relationship between wages and export shares.

Looking at the relationship that could exist between unit labour costs and export quantities, it is expected that there should be a negative correlation between them. If the relative cost per unit of output from an industry is low, then that industry is expected to produce and export more of its products. Therefore, an industry with a lower cost of production will tend to have larger export shares. This hypothesis is strictly based on a negative linear relationship between unit labour cost and export quantities. Many empirical investigations have found this to be true (Balassa,1963: 236).

In view of the above discussion, the models to be estimated follow Balassa's (1963) and are formally presented as:

$$
\begin{aligned}
& \log \left(X_{i, t} / M_{i, t}\right)=\alpha_{0}+\alpha_{1} \log \operatorname{RelProd}_{i, t}+\varepsilon_{i, t} \\
& \log \left(X_{i, t} / M_{i, t}\right)=\beta_{0}+\beta_{1} \log \operatorname{RelProd}_{i, t}+\beta_{2}{\log \operatorname{RelWages}_{i, t}}+\varepsilon_{i, t} \\
& \log \left(X_{i, t} / M_{i, t}\right)=\lambda_{0}+\lambda_{1} \operatorname{LogRULC}_{i, t}+\varepsilon_{i, t}
\end{aligned}
$$


Such that; $\alpha_{0}, \beta_{0}$, and $\lambda_{0}$ can be $>$ or $<0 . \alpha_{1}$ and $\beta_{1}>0 . \beta_{2}$ can be $>$ or $<0 . \lambda_{1}<0$. Where $X_{i, t}$ is the exports of South Africa to the United States in industry i for year $t, M_{i, t}$ is the imports of South Africa from the United States in industry i for year $t$. RULC, RelProd, and RelWages are unit labour costs, labour productivity, and wages in South Africa relative to those of the United States respectively. All the variables included in the specification are in natural logarithm form.

As clearly indicated above, a test of the Ricardian theory of comparative advantage is carried out in this study. A panel data econometric technique is adopted in estimating the required model of the Ricardian theory and 23 cross-sectional data points of the major manufacturing industries in South Africa are employed. The use of panel data in this study refers to the pooling of observations across the selected industries over the specified time periods. The advantages of advancing from the cross-sectional estimations to using a panel data estimation technique is that the efficiency of estimating the parameters will be improved when combining the data. It also gives more informative data, more variability, less collinearity among variables and more degrees of freedom. The sector specific effects and time specific effect can easily be seen in a panel data model and the effect of omitted variable bias is reduced. All these benefits of panel data estimation are mentioned in Hsiao (1985, 1986), Klevmarken (1989: 525) and Solon (1989: 488).

However, following the Ricardian theory and the ideas of the previous empirical studies the equations estimated in this study are divided into two parts. The first part is the one-way error component model and the second part is the two-way error component model. Each part consists of three equations. The first equation investigates the relationship that exists between relative productivity and relative export of South Africa and the U.S. Relative wages are added in the second equation as an explanatory variable to see whether the explanation of export ratios given in equation one can be improved upon. The third equation looks at the relationship that exists between relative unit labour cost and relative export of South Africa and U.S.

The reasons for estimating the above specifications are that, it is necessary to see the industry specific effects and the time specific effects of the regressions, which were not emphasized in the earlier empirical studies. This means that, it will be possible to figure out which industries affect the pattern of trade between South Africa and the U.S. positively or negatively. The time specifics also allow us to see which year has had favourable and/or unfavourable trade patterns in South Africa. These equations show the impact of relative unit labour costs, relative productivity, and relative wages on the export performance of South Africa across industries over the period that is investigated.

\subsection{Data description}

The data that is used on all the variables in the specifications above are obtained from the trade data websites. The export data are taken from http://trade.easydata.co.za using the SIC 2 digit. Labour employment, Value Added, 
and Wage data were obtained from the UNIDO Industrial Statistics (ISIC 3 Digit) and the bilateral exchange rates figures were taken from the South African Reserve Bank Database. The relative export variable was calculated as the ratio of South African export to South African imports to and from the United States. Relative productivity, relative wages, and relative unit labour costs were all calculated as ratios of South Africa to United States ${ }^{1}$. These variables are transformed into real figures using the GDP deflator of South Africa and that of the United States. It was unnecessary to transform the export figures into real figures since what is of interest is to know the amounts of exports in a given year.

For the purpose of this study, it is necessary to exclude some industries from the sample. This follows the idea of Balassa (1963: 232), that those industries whose output did not exceed one-third of one percent of the value of manufacturing production in the two countries have not been included in the estimations. He tries to explain that these industries are not representative of manufacturing as a whole in both countries. Therefore, after careful and thorough examination of the major industries in South Africa, the sample covered 23 industries and these are presented in Appendix (1). Unavailability of data in some industries also contributed to eliminating them from the sample as the study covers the period 1994 to 1999. The study intended initially to cover the period 1994 to 2004. Due to a lack of data for some variables it covers the period 1994 to 1999 . However, the unavailability of data up to the current period does not affect the robustness of the estimated coefficients of the regressions. This is because there have not been any major changes in the structure of the South African economy since 1999.

The use of bilateral export ratios follows the original formulation of the Ricardian theory. Previous specifications by MacDougall (1951) and Stern (1962) have used total export ratios in their studies on the US-UK trade pattern. They tended to analyse the relationship between total export ratio and labour productivity ratio and/or unit labour cost ratio. Balassa (1963) tried to compare the American and the British exports and found that tariffs between the two countries greatly influence trade that exists between them. He, however, excludes trade between the two countries and therefore uses the total export ratios to a third market. This has also been criticized by Golub and Hseih (2000: 226) who used bilateral trade flows in testing the Ricardian theory. Their results were significant and consistent to the theory.

The stationarity of the data used were tested for using Im, Pesaran and Shin (IPS) (2003) unit roots test. Each series is first tested assuming a constant, but no trend, and secondly, for a constant and trend. The relative export series is found to be stationary both at constant, no trend and with constant and trend. Relative Unit Labour Costs (RULC) and Relative Productivity (RelProd) are found to be trend stationary, but non-stationary at constant, no trend. The Relative Wages series is found to be non-stationary both at constant, no trend and constant and trend. From the stationarity test, there is a need for a cointegration test only for equation 5(b)

${ }^{1}$ The calculation of each variable follows the specification laid out in equation 3 \& 4 . 
since there is a presence of non-stationary variable in the equation. All other variables in equation 5(a) and 5(c) are stationary ${ }^{2}$.

The cointegration test is performed following the IPS unit roots test. This is as a result of the residual based test that is being adopted in this paper. The result shows that there is cointegration in equation 5(b) only at constant, no trend. This means that the normal, traditional estimation of panel data can be carried out for the three equations and since all the variables used in the other equations 5(a) and 5(c) are stationary.

\section{Estimation results}

\subsection{Diagnostic tests}

Before analyzing the results of the various estimated equations it is imperative to test the various diagnostics of the panel estimations ${ }^{3}$.

The results of the poolability tests conducted, shows that all three equations that were estimated do not have the same parameters over time and across industries. This means that the fixed effect model is the appropriate model to be estimated in this paper.

The Hausman test for exogeneity reveals that relative productivity and relative wages in equation 5(a) and 5(b) are endogenous while relative unit labour cost in equation 5(c) is found to be exogenous. That is to say that, the use of OLS in estimating equation 5(a) and 5(b) will result in biased and inconsistent estimates. But since equation 5(c) is free from the endogeneity problem, OLS estimation is adopted for it.

The test on serial correlation follows the procedure laid down by Bhargava, Franzini and Narendramathan (1982). The test results shows that there is serial correlation in the error component. Correction for this problem was performed and the result shows that the residuals from each equation are found to be free from serial correlation. However, the estimations can now be performed with the transformed series, which will lead to unbiased and efficient estimate of the regression coefficient.

\subsection{Fixed effects estimations}

Based on the results of the diagnostic tests conducted in Section 5.1, the poolability test suggests the use of a fixed effect model. The Hausman test for exogeneity reveals that relative productivity and relative wages are endogenous in equation 5(a) and 5(b). This resulted in adopting the Two-Stage Least Square procedure to correct the problem of endogeneity in estimating the two affected equations. The

\footnotetext{
${ }^{2}$ The results of the unit roots and cointegration tests are presented in Appendix $2 \& 3$.

${ }^{3}$ The results of the diagnostic tests are also presented in Appendix 4.
} 
lagged values of the independent variables in each equation are used as an instrumental variable in correcting for this problem. The normal OLS estimation is carried out for equation 5(c) since relative unit labour cost is detected to be free from an endogeneity problem.

However, the results of the various estimations conducted in this paper are presented in Table 1. The result is presented in a One-Way and Two-Way error component model as specified in section four.

Table 1. Estimated results for the one way and the two way error component model.

Dependent Variable: Relative Exports (RE)

\begin{tabular}{|c|c|c|c|c|c|}
\hline \multicolumn{4}{|c|}{ One Way Error Component Model } & \multicolumn{2}{|c|}{ Two Way Error Component Model } \\
\hline \multirow[t]{2}{*}{ Variables } & \multicolumn{2}{|c|}{ Coefficients } & & \multicolumn{2}{|c|}{ Coefficients } \\
\hline & $5 \mathbf{a}$ & & & $5 a$ & 5c \\
\hline RelProd & 0,48 & 0,75 & & 1,22 & \\
\hline RelWages & & $-0,59$ & & & \\
\hline RULC & & & $-0,5$ & & $-1,541$ \\
\hline \multicolumn{6}{|c|}{ Fixed Effects (Cross-Sections) } \\
\hline Basic chemicals & 0,2069 & 0,4925 & 2,0888 & 0,8029 & 4,6019 \\
\hline Beverages & 0,9258 & 1,5214 & 1,3442 & 0,9766 & 2,3052 \\
\hline Elect. Machinery & $-2,2479$ & $-2,8101$ & $-1,7505$ & $-2,8973$ & $-1,4362$ \\
\hline Food & 0,1166 & 0,2497 & 0,6212 & 0,1170 & 1,3259 \\
\hline Footwear & $-3,2944$ & $-2,3051$ & $-1,8070$ & $-3,3605$ & $-0,0577$ \\
\hline Furniture & 1,5199 & 1,5467 & 1,7182 & 1,3907 & 2,0281 \\
\hline Glass & 1,4909 & 1,6731 & 0,8250 & 1,9989 & 0,1277 \\
\hline Iron \& Steel & 4,3171 & 5,0298 & 3,9442 & 4,8754 & 4,0707 \\
\hline Leather & 2,4412 & 3,1193 & 2,8134 & 2,6430 & 3,5684 \\
\hline $\begin{array}{l}\text { Machinery \& } \\
\text { Equipment }\end{array}$ & $-1,1642$ & $-1,8746$ & $-1,8696$ & $-1,1942$ & $-3,0389$ \\
\hline Metal products & 0,0497 & 0,1043 & 0,0398 & 0,1353 & 0,0985 \\
\hline Non-Ferrous Metals & 3,5065 & 4,0444 & 2,3011 & 4,5155 & 1,1986 \\
\hline Other industries & 1,3650 & 1,1396 & 0,6088 & 1,7211 & 0,4830 \\
\hline Paper & 0,2636 & 0,1869 & 0,2312 & 0,2507 & 0,1003 \\
\hline Plastic products & $-1,1500$ & $-1,4509$ & $-1,8048$ & $-0,9985$ & $-2,6172$ \\
\hline Printing & $-3,0048$ & $-3,4360$ & $-3,5916$ & $-2,9752$ & $-4,3918$ \\
\hline $\begin{array}{l}\text { Prof \& Scientific } \\
\text { Equipment }\end{array}$ & $-2,1036$ & $-3,6242$ & $-3,7696$ & $-1,9559$ & $-6,7055$ \\
\hline Rubber products & 0,4407 & 0,5058 & 0,0497 & 0,6670 & 0,2769 \\
\hline Textiles & 0,2143 & 0,1857 & 0,0906 & 0,3672 & 0,4542 \\
\hline Tobacco & $-4,6858$ & $-5,0310$ & $-3,0491$ & $-5,7840$ & $-1,5041$ \\
\hline Transport Equip. & $-1,0317$ & $-1,3091$ & $-1,6777$ & $-0,8046$ & $-2,6107$ \\
\hline Wearing apparel & 2,7641 & 3,1427 & 3,2716 & 2,6051 & 4,2273 \\
\hline Wood Products & $-0,9397$ & $-1,1007$ & $-0,3671$ & $-1,2565$ & $-0,0054$ \\
\hline \multicolumn{6}{|c|}{ Fixed Effects (Period) } \\
\hline 1994 & & & & & 0,4395 \\
\hline 1995 & & & & 0,3706 & $-0,2090$ \\
\hline 1996 & & & & 0,0397 & $-0,0587$ \\
\hline 1997 & & & & 0,0466 & $-0,0219$ \\
\hline 1998 & & & & $-0,1287$ & $-0,2153$ \\
\hline 1999 & & & & $-0,3282$ & $-0,3526$ \\
\hline R-Squared & 0,97 & 0,98 & 0,97 & 0,97 & 0,97 \\
\hline Adj R-Squared & 0,96 & 0,97 & 0,96 & 0,96 & 0,96 \\
\hline \multirow{4}{*}{$\begin{array}{l}\text { Test-Statistic: } \\
\text { RelProd } \\
\text { RelWages } \\
\text { RULC }\end{array}$} & & & & & \\
\hline & 5,22 & 7,18 & & 2,16 & \\
\hline & & $-3,49$ & & & \\
\hline & & & $-4,4$ & & $-2,92$ \\
\hline
\end{tabular}

Source: Authors' own calculations; Eviews 5 


\subsubsection{Relative productivity and relative exports}

Equation 5(a) in Table 1 shows the result of how productivity differences have affected the pattern of trade that exists between South Africa and the United States. The one-way error component model, reveals that the South African output per worker over the years has enhanced its exports of manufacturing products to the United States. That is, a one percent increase in the South Africa-U.S. productivity ratio will lead to about 0.5 percent increase in its export shares. About 97 percent of the variation in export ratio is explained by differences in productivity and the result is found to be statistically significant at one percent level. This is in conformity with the earlier empirical tests of Macdougall (1951), Stern (1962), and Balassa (1963). The result shows that labour productivity in South Africa is playing a significant role in explaining the pattern of trade with the United States.

In the two-way error component model, a similar result is found and the relationships that exist between the two variables have not changed. The estimated coefficient is more than twice the coefficient of the one-way error component model. This reveals that a one percent increase in relative productivity will lead to about 1.2 percent increase in export ratio. The reason for this may be as a result of the time dimension that is incorporated into the model.

\subsubsection{Relative productivity, relative wages, and relative exports}

The question of whether the explanation of export shares in South Africa can be improved upon by adding relative wages to productivity differences as an explanatory variable is answered in equation 5(b) in Table 1 . Table 1 shows that an increase in relative productivity by one percent will lead to about 0,75 percent increase in export shares. A decrease of one percent in South African wages, relative to that of the United States will lead to about 0,6 percent increase in its export shares. There is an increase of about 0,25 percent for the coefficient of relative productivity as a result of the wage ratio that is added to the estimation. The relationship that exists between relative wages and relative exports contradict the result of the multivariable equation in Balassa (1963), which is based on a cross-section estimation. However, the panel results presented in this paper are assumed to be the most reliable since the efficiency of the parameter estimates is improved on as a result of combining the data across cross-section and time.

The variation in the export ratio that is explained by the two variables shows that the addition of relative wages in the explanation of export shares in South Africa did not give a significant difference when compared to differences in productivity alone as a determinant of export shares. About 98 percent of the variation in export ratio can be explained by relative productivity and relative wages and this result is statistically significant at a one percent level. There is about 0,1 percent increase when compared to the result in equation 5(a). This reveals that the pattern of trade that exists between South Africa and the United States is not driven much by differences in wages. 


\subsubsection{Relative unit labour costs and relative exports}

The question of whether the pattern of trade between South Africa and the United States is driven by relative unit labour costs is resolved in the result presented in equation 5(c) in Table 1. This shows that a one percent decrease in the costs per unit of labour in South Africa relative to that of the U.S will lead to about 0,5 percent increase in its export shares. The variation in export shares that is being explained by relative unit labour costs is found to be about 97 percent and this result is statistically significant at a one percent level. The estimated coefficient and the coefficient of determination are similar to that of equation 5(a). This means that productivity differences and differences in the costs of labour between the two countries are the major determinant of trade pattern between South Africa and the U.S. Similar results were found in Balassa's (1963) cross-sectional examination, and in that of Golub (1994). The result also conforms to the result of Golub and Hsieh's (2000) and of Edward and Golub's (2002).

The two-way error component model shows that the same relationship is found between the two variables. The only difference is that the estimated coefficient has increased more than three times that of the coefficient in the one-way error component model. This shows that a one percent increase in relative unit labour costs will lead to about 1,54 percent decrease in export ratio.

\subsubsection{The industry-specific effects}

The result of the cross-sectional effects presented in Table 1 shows the various industries, which have had a positive or negative impact on the pattern of trade in South Africa. A negative value reflects a negative impact, while a positive value reflects a positive impact. The sign for each of the industries in each of the three equations estimated correspond to each other and are presented for both the oneway and the two-way models.

It is found that 13 of the 23 industries that are selected have played a significant role in improving the pattern of trade that exists between South Africa and the U.S. The remaining 10 industries have affected the pattern of trade that exists between the two countries negatively. When looking critically at these industries, it can be pointed out that those industries with a positive effect on the pattern of trade are probably those industries in which South Africa has a comparative advantage. South African comparative disadvantage may also be linked to those industries which affected the trade pattern negatively. This means that South Africa will probably have to import those goods from the U.S.

\subsubsection{The time-specific effects}

The result of the time effect is presented in the two-way model of Table 1. This shows the various years in which the pattern of trade is affected positively or negatively. Table 1 show that the pattern of trade in South Africa to the U.S has been negatively affected from 1995 to 1999 . This may be as a result of the new trend of 'trade liberalization' that shifted trade in South Africa to other export 
destinations. The structural change in 1994 as a result of the new democratic dispensation experienced in South Africa also has to be taken into account. This has opened a wider market for South Africa to re-diversify its exports to other emerging markets and the influence of global development in trade in recent years.

Moreover, the relationship that exists between relative productivity, relative wages, relative unit labour costs and relative exports has been established in the discussion above. The next section presents the conclusion and recommendations of the paper in general.

\section{Conclusions}

The estimations performed in this paper on the Ricardian theory of comparative advantage tried to extend Golub's (2000) framework. The pattern of trade between South Africa and the U.S was determined, firstly, on the basis of differences in productivity, and secondly, wage differentials were added to see the improvement therein. Lastly, the analysis was extended by using differences in unit labour costs between the two countries in determining the pattern of trade. Trade values were also used in the study instead of trade volumes and the paper assumes that there are no transportation costs and other barriers to trade as these could lead to a big difference between these two countries in terms of their export list.

Based on the estimated results, it is shown that labour productivity in South Africa is playing a big role in explaining the pattern of trade with the U.S. Therefore, the estimated panel result reveals that an improvement in South Africa's labour productivity is a necessary condition. It can lead to the growth of its export sectors.

The estimate and the coefficient of determination $\left(\mathrm{R}^{2}\right)$ of the relative unit labour costs are found to be similar to that of the relative productivity. This means that these two variables play a similar role in explaining the export ratio, but in a different direction.

When decomposing the effects of relative unit labour costs into relative productivity and relative wages it is found that relative productivity is still the major determinant of trade rather than relative wages. The wage differentials did not make any significant improvement in explaining the trade between South Africa and the U.S. To support this inference, Taussig (1921: 481) in his defence of the Ricardian theory, expressed his opinion that wages and capital costs are not sufficiently important to make significant changes to the trade flows as determined by relative differences in productivity.

However, the major findings of this paper are that relative unit labour costs and relative productivity are the major determinants of trade patterns between South Africa and the U.S in the manufacturing sector and this conforms to the Ricardian theorem.

Finally, future research should attempt to focus on policy implications in further enhancing the potential of these very important sectors. 


\section{References}

Anon. Not Dated. South Africa trade with North America. [Online] Available from: http://www.southafrica.info/doing business/sa trade/agreements/trade northamerica.htm [Accessed: 2006-3-3].

Anon. Not Dated. Manufacturing in South Africa. [Online] Available from: http://www.southafrica.info/doing_business/economy/key_sectors/manufacturing.htm [Accessed: 2006-3-3].

Balassa, B (1963): “An Empirical Demonstration of Classical Comparative Cost Theory”, The Review of Economics and Statistics, 45(3), 231-238.

Barro, R J and Bala-i-Martin, X X (1995): Economic Growth, New York: McGraw Hill.

Bhagwati, J (1964): “The Pure Theory of International Trade: A Survey”, The Economic Journal, 74(293), 1-84.

Bhagwati, J (1967): “The Proofs of the Theorems on Comparative Advantage", The PEconomic Journal, 77(305), 75-83.

Bhargava, A, Franzini, L and Narendranathan, W (1982): "Serial Correlation and Fixed Effects Model”, Review of Economic Studies, 49, 533-549.

Carlin, W, Glyn, A and Van Renen, J (2001): "Export Market Performance of OECD Countries: An Empirical Examination of the Role of Cost Competitiveness”, The Economic Journal, 111, 128-162.

Chipman, J S (1965): “A Survey of the Theory of International Trade: Part 1, The Classical Theory”, Econometrica, 33(3), 477-519.

Edwards, L and Golub, S (2002): “South Africa's International Cost Competitiveness and Productivity: A Sectoral Analysis”, Report prepared for the South African National Treasury under a USAID/Nathan Associates SEGA Project.

Golub, S (1994): “Comparative Advantage, Exchange Rates, and Sectoral Trade Balances in Major Industrial Countries”, IMF Staff Papers, 41(2), 286-312.

Golub, S S and Hsieh, C (2000): “Classical Ricardian Theory of Comparative Advantage Revisited”, Review of International Economics, 8(2), 221-234.

Graham, F D (1932): “The Theory of International Values”, The Quarterly Journal of Economics, 46(4), 581-616.

Hsiao, C (1985): “Benefits and Limitations of Panel Data”, Econometric Reviews, 4, 121-174.

Hsiao, C (1986): Analysis of Panel Data, Cambridge: Cambridge University Press.

Im, K S, Pesaran, M H and Shin, Y (2003): “Testing for Unit Roots in Heterogeneous Panel”, Journal of Econometrics, 115(1), 53-74.

Klevmarken, N A (1989): "Panel Studies: What Can We Learn from Them? Introduction”, European Economic Review, 33, 523-529.

Kohler, M R A and Bruce-Brand, J O (2003): “Comparative Cost Advantage and Trade Performance in South African Manufactures: 1970-2000”, Paper presented at the 2003 Annual Conference of the South African Economic Society.

Leontief, W W (1933): "The Use of Indifference Curves in the Analysis of Foreign Trade”, The Quarterly Journal of Economics, 47(3), 493-503. 
MacDougall, G D A (1951): "British and American Exports: A Study Suggested by the Theory of Comparative Costs Part 1”, The Economic Journal, 61(244), 697-724.

Miller, S M and Upadhyay, M P (2000): "The Effects of Openness, Trade Orientation, and Human Capital on Total Factor Productivity”, Journal of Development Economics, 63, 399-423.

Ricardo, D (1817) (1951): Principles of Political Economy and Taxation, New York: Penguin.

Romer, P (1992): “Two Strategies for Economic Development: Using Ideas and Producing Ideas", World Bank Conference on Economic Development, The World Bank, Washington DC.

Ruffin, R J (2002): “David Ricardo’s Discovery of Comparative Advantage”, History of Political Economy, 34(4), 727-749.

Seligman, E R (1911): “Ricardo and Torrens”, The Economic Journal, 21(83), 448-468.

Smith, Adam (1776) (1965): An Inquiry into the Nature and Causes of the Wealth of Nations, All page references are to the Cannan Edition (1950), London: Methuen.

Solocha, A (1991): “Comparative Cost Advantage and Trade Performance: A Panel Data Approach”, The International Trade Journal, 5(3), 403-417.

Solon, G S (1989): “The Value of Panel Data in Economic Research”, in D Kasprzyk, G J Duncan, G. Kalton and M P Singh, (eds): Panel Surveys, New York: John Wiley and Sons, 486-496.

Stern, R M (1962): "British and American Productivity and Comparative Costs in International Trade, Oxford Economic Papers, New Series, 14(3), 275-296.

Stryker, J D (1968): “The Sources of Change in Export Performance: The United States and Canada”. In Kenen, Peter, and Roger Lawrence (Eds): The Open Economy: Essays on International Trade and Finance, New York: Columbia University Press, 150-174.

Taussig, F W (1921): Principles of Economics, Vol.1, New York: Macmillian.

Torrens, R (1815): Essay on the External Corn Trade, London: J. Hatchard.

West, E G (1990). Adam Smith and Modern Economics: From Market Behaviour to Public Choice, England: Edward Elgar. 


\section{Industries}

\section{APPENDICES}

1. Basic chemicals

2. Beverages

3. Electrical Machinery

4. Food

5. Footwear

6. Furniture

7. Glass

8. Iron \& Steel

9. Leather

10. Machinery \& Equipment

11. Metal products

12. Non-Ferrous Metals

13. Other industries

14. Paper

15. Plastic products

16. Printing

17. Prof \& Scientific Equipment

18. Rubber products

19. Textiles

20. Tobacco

21. Transport Equipment

22. Wearing apparel

23. Wood Products

2. The IPS Unit Roots Tests - in Levels

\begin{tabular}{|l|l|l|l|}
\hline SERIES & MODEL & t-BAR & CONCLUSION \\
\hline RelExport & $\begin{array}{l}\text { Constant no Trend } \\
\text { Trend \& Constant }\end{array}$ & $\begin{array}{l}-3,0208^{* * *} \\
-3,6297^{*}\end{array}$ & Stationary \\
\hline RULC & $\begin{array}{l}\text { Constant no Trend } \\
\text { Trend \& Constant }\end{array}$ & $\begin{array}{l}-0,5932 \\
-8,5179 * * *\end{array}$ & $\begin{array}{l}\text { Non-Stationary } \\
\text { Stationary }\end{array}$ \\
\hline RelProd & Constant no Trend & $-0,5177$ & $\begin{array}{l}\text { Non-Stationary } \\
\text { Stationary }\end{array}$ \\
& Trend \& Constant & $-6,91999^{* * *}$ & $\begin{array}{l}\text { Non-Stationary } \\
\text { Non-Stationary }\end{array}$ \\
\hline RelWages & Constant no Trend & $-0,8387$ & $-3,0008$ \\
& Trend \& Constant & & \\
\hline
\end{tabular}

$\left(^{* *}\right)\left(^{*}\right)$ Significant at 1\% (5\%) (10\%) level using the IPS Critical values:

$-2,51(-2,11)(-1,96)$ respectively.

Source: Authors' own calculations; Eviews 5 
3. The Cointegration Tests - in Levels

\begin{tabular}{|l|l|l|l|}
\hline EQUATIONS & MODEL & t-BAR & CONCLUSION \\
\hline 5(b) & Constant no Trend & $-1,9827^{*}$ & $\begin{array}{l}\text { Cointegrated } \\
\text { No Cointegration }\end{array}$ \\
& Trend \& Constant & $-2,5952$ & \\
\hline
\end{tabular}

$\left(^{* *}\right)\left(^{*}\right)$ Significant at 1\% (5\%) (10\%) level using the IPS Critical value

Source: Authors' own calculations; Eviews 5

\section{Diagnostic Tests}

\begin{tabular}{|l|l|l|l|l|}
\hline Test Type & \multicolumn{3}{|c|}{$\begin{array}{c}\text { Test Statistics } \\
\text { (Critical Values) }\end{array}$} & Conclusion \\
& \multicolumn{2}{|c|}{ 5a } & \multicolumn{1}{|c|}{$\mathbf{5 c}$} & \\
\hline Poolability & 17,94 & 8,77 & 22,28 & Not Poolable \\
& $(1,5)$ & $(1,53)$ & $(1,5)$ & \\
\hline Hausman & 6,94 & 22,97 & 0,007 & Only 5c is \\
& $(3,84)$ & $(5,99)$ & $(3,84)$ & Exogenous \\
\hline Serial & 2,67 & 2,63 & 2,64 & No Serial \\
Correlation & $\left(\mathrm{d}_{\mathrm{pL}}: 1,81 \&\right.$ & $\left(\mathrm{d}_{\mathrm{pL}}: 1,795 \&\right.$ & $\left(\mathrm{d}_{\mathrm{pL}}: 1,81 \&\right.$ & Correlation \\
& $\left.\mathrm{d}_{\mathrm{pU}}: 1,82\right)$ & $\left.\mathrm{d}_{\mathrm{pU}}: 1,838\right)$ & $\left.\mathrm{d}_{\mathrm{pU}}: 1,82\right)$ & \\
& &
\end{tabular}

$5 a, 5 b$, and $5 c$ are the various equations that are specified in section 4

Source: Authors' own calculations; Eviews 5 
